\title{
Peculiarities of Public Administration of Development of Small Business in Modern Conditions
}

Doi:10.5901/mjss.2014.v5n12p87

Ph.D. Bagautdinova N.G.

Ph.D. Kumpilova A.R.

Ph.D. Boganchikova I.O

Ph.D., Shakhnina I.Z.

\begin{abstract}
The article considers peculiarities and characteristics of public regulation of small business including distribution of powers and responsibilities in this sphere, as well as formation of the system of performance indicators of activity of self-regulated organization of small business enterprises concerning management of development of small business potential. The performed in conclusion analysis of effectiveness of small business development in the frames of public regulation, as well as in the frames of self-regulated structure, confirms priority of choice of self-regulated scenario.
\end{abstract}

Keywords: entrepreneurship, business activity, state regulation, self-regulation, entrepreneurship development.

\section{Introduction}

Ideology of state regulation of business activity is based on the fact that its successful development is possible only with favorable finance, economic, legal and political conditions. Absence of such conditions makes entrepreneurship support very inefficient.

Activity of entrepreneurship entities greatly depends on activity of federal public executive authorities. However, there are several problems in the sphere of state regulation and control of business activity, such as: absence of integral legislative system of administrative-legal regulation of business activity; imperfection of tax system; unsteadiness of budgetary financing of federal and regional business support programs; underdevelopment of mechanisms of financialcredit support and insurance against risks of enterprises; absence of reliable social security system and safety of businessmen; administrative barriers for business development.

According to World Bank, administrative barriers, tax burden and corruption are the main obstacles for development of business in Russia. The resource centre of small business gives the following definition of administrative barriers: "business obstacles with which businessmen come across in process of their activity and which created by executive authorities officers". A lot of analysts think that administrative barriers are enterprise expenses connected with legislative execution and execution if a lot of regulatory documents, the so-called normative by-law acts $[1,10]$.

In the opinion of the authors of the program document "Struggle with administrative barriers for business development. Practice of EC countries" [1], there are several reasons for administrative barriers, and each of the reasons interferes business activities of economic entities. Firstly, "ineffective low-rank legislation" which lacks transparency and which is difficult for execution. To follow the legal way turns into great loss of time. Time costs or bribes that allow to escape them turn into great barriers. In fact, proposal o some structures to conduct registration of a new enterprise within a short time - but at a definite chanre - is also a bribe [2].

\section{Research Methodology}

Analysis and comparison of approaches of different schools for the problem of cooperation of state and business in market economy allows to draw the following conclusions. Firstly, mercantilists thought that participation of the state in regulation of economic processes by means of protectionism is necessary. However, physiocrats thought that only unlimited operation of natural economic laws positively influences development of the society. Also being against interference of the state into manufacturing industry, промышленность, they explained the important role of the state in ensuring of private ownership rights and development of market infrastructure [3]. 
Secondly, representatives of classical political economy asserted the necessity to provide "honest partnership" with business, as an important economic function of the state which is necessary for efficient operation of market mechanism. Followers of classical political economy assigned to the state the role of the guarantor of freedom of action of business entities that create social wealth [4], asserted "natural harmony" of economy and claimed for cancellation of state regulation of development of manufacturing industry and trade [5].

Thirdly, followers of the German historical economic school thought that in conditions of market economy the state has to be in active cooperation with private companies, to create material, institutional and cultural prerequisites for fast industrial recovery of the country; to form and develop the single domestic market; to coordinate public interests and to direct efforts of the nation to implementation of strategic long-term objectives.

Fourthly, neoclassicists of the XIX century assumed that economic development is supported automatically thanks to "free" competition (laissez faire), i.e. to laws of self-regulation and balance of market economy $[5,6]$.

Fifthly, representatives of the Keynesian school denied self-regulation of market economy; they think that the state has to play very important role in market economic system and to be an active partner of private capital [6].

Sixthly, economic liberalists of the XX century were against state interference in the economy thinking that it could undermine the market mechanism and to paralyze the economic system in the whole. As for cooperation of the state and business, they determined it only by performance of institutional functions connected with maintenance of natural social order based on freedom of choice and development of business competition [7].

Seventhly, followers of institutional economics of the XX century justified ideas concerning necessity of state influence on obvious "defects" of market mechanism connected with fast growth of social inequality, monopolization and crises, divergence of private and public interests [8, 9].

\section{Development of Integrated Evaluation System Of Management of Small Business Development}

Formation of the system of state regulation of small business in modern Russian conditions is complicated by the fact that existing measurement methods of business activity of small enterprises have rather low degree of flexibility [11], in the result of which tendencies of small business development - monitoring of which is implemented with their help - greatly changes by the moment of processing of results what does not allow to manage activity of business entities of this type efficiently in because of absence of efficient system of measurement of their current condition and development perspectives. Thus, efficient management of small enterprise activity on state level presupposes regulation in two directions: first of all, it is necessary to form stable institutional environment of development of small enterprises, including establishment and maintenance support of formal enforcement institutions in steady form what will allow to establish steady informal institutions of regulation of small business and to provide reliability of organizational links of control of small business development in the frames of implementation of state strategy of its development. In the process of implementation of state policy of small business development by key authority that provides implementation of the strategy on condition of observance of necessary level of flexibility of regulation, it should be coordinating the activity of local small business enterprises self-regulated control body which acts in the frames formed on the first stage of regulation by formal institutions.

Implementation of proposed approach presupposes state regulation of potential of small business development in accordance with presented in Table 1 Matrix of responsibility (in Matrix 0 means "responsible", y - "takes part in implementation of the function", $И$ - "gets information concerning implementation of the function"). Matrix of responsibility formed using the specified terms is presented in Table 1.

Table 1: Matrix of responsibility of state regulation of development potential of small enterprises in Russian economy

\begin{tabular}{|c|c|c|c|c|}
\hline № & Regulation function & $\begin{array}{c}\text { State run public } \\
\text { authorities }\end{array}$ & $\begin{array}{c}\text { Self-regulated } \\
\text { organization of small } \\
\text { enterprises }\end{array}$ & $\begin{array}{c}\text { Small } \\
\text { enterprises }\end{array}$ \\
\hline 1 & 2 & 3 & 4 & 5 \\
\hline 1 & Formation of strategy of development of small business potential & 0 & $\mathrm{y}$ & n \\
\hline 2 & $\begin{array}{l}\text { Formation of set of measures for implementation of strategy of } \\
\text { development of small business potential }\end{array}$ & n & 0 & $\mathrm{y}$ \\
\hline 3 & $\begin{array}{l}\text { Identification of provision of resources of set of measures for } \\
\text { implementation of strategy of development of small business potential }\end{array}$ & n & 0 & $\mathrm{y}$ \\
\hline 4 & $\begin{array}{l}\text { Update of the program of provision of resources of set of measures for } \\
\text { implementation of strategy of development of small business potential in }\end{array}$ & n & 0 & $\mathrm{y}$ \\
\hline
\end{tabular}




\begin{tabular}{|c|c|c|c|c|}
\hline & case of change of factors of inside and outside environment & & & \\
\hline 5 & $\begin{array}{l}\text { Formation of set of measures of encouragement of development of small } \\
\text { business potential }\end{array}$ & $\mathrm{y}$ & $\mathrm{O}$ & $\mathrm{y}$ \\
\hline 6 & Monitoring of small business potential and perspectives of development & n & 0 & $\mathrm{y}$ \\
\hline 7 & Update of strategy of development of small business potential & 0 & $\mathrm{y}$ & И \\
\hline 8 & $\begin{array}{l}\text { Development of normative legal acts for regulation of small enterprise } \\
\text { activity }\end{array}$ & И & O & $\mathrm{y}$ \\
\hline 9 & $\begin{array}{c}\text { Introduction of initiative for adjustment of regulatory normative legal base of } \\
\text { small business potential development }\end{array}$ & O & И & И \\
\hline 10 & $\begin{array}{c}\text { Implementation of activity and development of potential of small business } \\
\text { enterprises }\end{array}$ & n & И & 0 \\
\hline
\end{tabular}

As it is seen in the table, powers and responsibility for realization of great part of regulatory control are implemented by self-regulated organization of small enterprises, and it allows to provide potential management flexibility and reliability of this sphere which is necessary on modern stage of development of Russian economy.

As the analysis of domestic practice of activity of self-regulated organizations showed, performance by them the functions of the main coordinator of development of definite sphere of economic activity is not always effective, so that state run public authorities have to implement monitoring of activity of such organizations in the process of regulation by them the potential of small business development in order to implement appropriate timely adjustment of their activity in case of variation from parametric indicators of strategy carrying out. Solution to problem in hand presupposes necessity to use multi-factor estimate of activity of self-regulated organizations in view of performance of key control functions formulated in the thesis research work, in the frames of which self-regulated organization is the responsible one (see Table 2).

Table 2: System of performance indicators of activity of self-regulated organization of small business enterprises of management of small business potential development

\begin{tabular}{|c|c|c|}
\hline № & Regulation function & Performance indicator of regulation results \\
\hline 1 & $\begin{array}{c}\text { Formation of set of measures for implementation of strategy of small } \\
\text { business potential development }\end{array}$ & 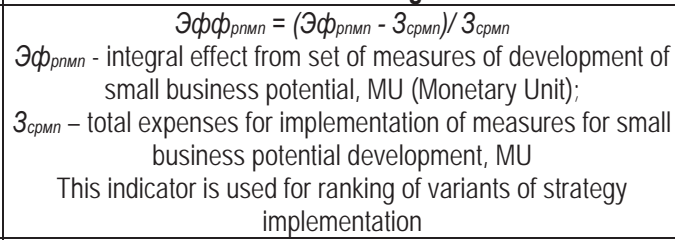 \\
\hline 2 & $\begin{array}{l}\text { Identification of resource provision of set of measures for } \\
\text { implementation of strategy of small business potential development }\end{array}$ & 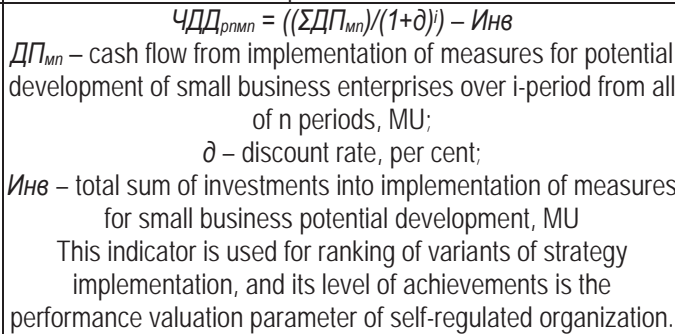 \\
\hline 3 & $\begin{array}{l}\text { Update of program of resource provision of set of measures for } \\
\text { implementation of strategy of small business potential development } \\
\text { in case of change of factors of inside and outside environment }\end{array}$ & 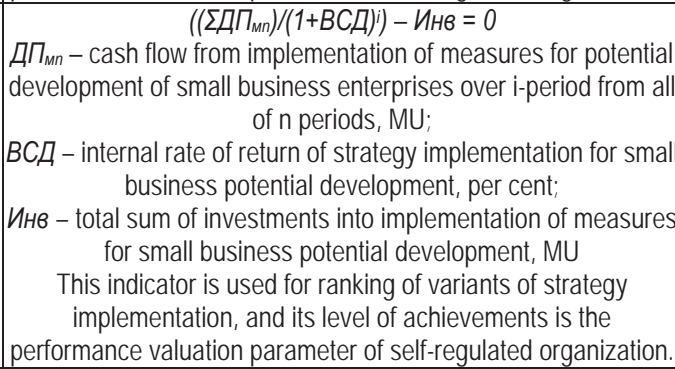 \\
\hline 4 & $\begin{array}{l}\text { Formation of set of measures of encouragement of development of } \\
\text { small business potential }\end{array}$ & $\begin{array}{c}\text { Прәпмn }=4 Д Д_{м n}-4 Д Д_{\text {pnмn }} \\
4 Д Д_{\text {рnмn }}-\text { net present value from activity of small business }\end{array}$ \\
\hline
\end{tabular}




\begin{tabular}{|c|c|c|}
\hline & & $\begin{array}{l}\text { enterprises in the result of implementation of measures for small } \\
\text { business development potential, MU; } \\
\text { чДД } \\
\text { enterprises in case of absence of implementation of measures } \\
\text { for small business development potential, MU } \\
\text { This indicator is used for ranking of variants of strategy } \\
\text { implementation, and its level of achievements is the } \\
\text { performance valuation parameter of self-regulated organization. }\end{array}$ \\
\hline 5 & $\begin{array}{l}\text { Monitoring of existing potential and development perspectives of } \\
\text { small business enterprises }\end{array}$ & 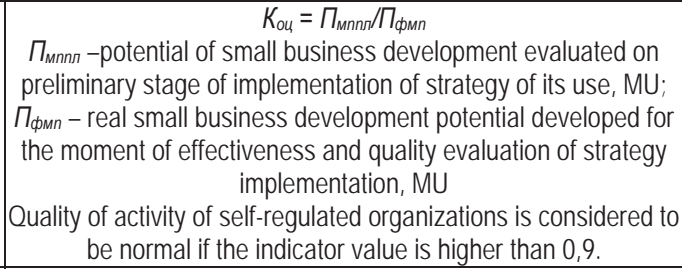 \\
\hline 6 & $\begin{array}{c}\text { Development of normative legal acts for regulation of small } \\
\text { enterprise activity }\end{array}$ & $\begin{array}{c}K_{\text {стр }}=K M_{u н с т} / K M_{\text {сов }} \\
\text { where } K M_{u н с т-} \text { number of impacts on institutional small } \\
\text { business environment initiated by self-organized organization, } \\
\text { item; } \\
K M_{c о в}-\text { total number of impacts on small business development } \\
\text { initiated by self-organized organization, item } \\
\text { The indicator value higher than } 0,5 \text { is prior. }\end{array}$ \\
\hline
\end{tabular}

Application of proposed complex of performance measuring indicators allows to reveal effectiveness and performance quality of self-regulated small business organizations, and to use the institutional environment so to carry out regulatory control of the organization in the frames of functioning formal institutions and enforcement institutions in case of disclosure of significant deviations.

\section{Results and Conclusion}

Research study of prevailing conditions of different countries for regulation of small business allowed to verify that quality and effectiveness of regulatory control, apart from extrapolation tendencies, are the most essential factors that influence tendencies of small business potential development in process of implementation of different approaches for state regulation; it allowed to forecast effectiveness of implementation of small business potential development strategy in the frames of three scenarios [13]:

- laissez-faire, in accordance with which the state follows the hands-off policy, and activity of small business enterprises is regulated by market factors;

- governmental regulation, in accordance with which small business regulation is implemented in the form of direct control which includes tax allowance, as well as subsidizing of activity of small business enterprises;

- self-regulation, in the frames of which regulation of small business enterprises is implemented by selfregulated organizations, while the state provides stability of formal and enforcement institutions.

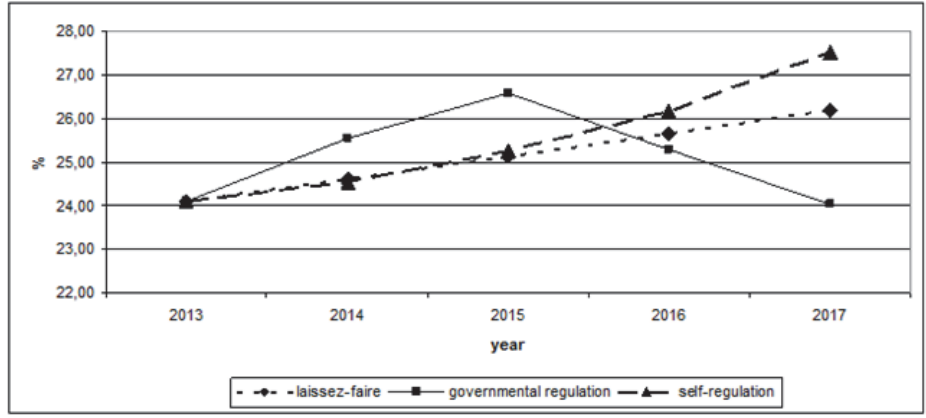

Pic. 1. Dynamics of efficiency of potential use of small business development for 2013-2017 (forecast) 
Results of forecasting of efficiency of small business potential calculated using described in this work methodological approach for 5-year perspective are presented on pic. 1 (calculation is made from imputed value of basic efficiency of potential use of small business development with the account of tendencies in the Russian Federation).

As it is seen from the data, despite the short-term improvement of the effectiveness of small business potential use in the process of implementation of state regulation, maximum effect is reached in case of implementation of selfregulation scenario. It means that implementation of methodological approaches and practical recommendations, relevance of which is confirmed by calculations of scenario, will allow to provide steady progressive dynamics of economic and social indicators of condition of national economy in whole and its territorial subdivisions.

The results confirm the thesis concerning necessity of prior self-regulation of small business development in transitive economies; it will allow to use advantages of flexibility and adaptability peculiar for self-regulated systems of control.

\section{References}

Stel v. A., Storey D., Thurik R. The effect of regulation of nascent and young entrepreneurship. Small Business Economics, Vol. 28, No. 2/3, March 2007, pp. 171-186.

Nystrom K. The institutions of economic freedom and entrepreneurship: evidence from panel data. Public Choice, Vol. 136, No. 3/4, Sep., 2008, pp. 269-282.

Isaeva, T.N., Safiullin, L.N., Bagautdinova, N.G., Shaidullin, R.N. Aspects of a multi-level study of competitive performance of objects and subjects of economic management // World Applied Sciences Journal, 27(13), 2013, 116-119.

Amable B. Institutional Complementarily and Diversity of Social Systems of Innovation and Production. - Review of International Political Economy, 2000. vol. 7. № 4.

Fakhrutdinova, E., Kolesnikova, J., Yurieva, O., Kamasheva, A. The commercialization of intangible assets in the information society/l World Applied Sciences Journal. Volume 27, Issue 13, 2013, Pages 82-86.

Glebova I.S., Sadyrtdinov R. and Rodnyansky D. Impact Analysis of Investment Attractiveness of the Republic of Tatarstan on Fixed Investments of its Leading Companies // World Applied Sciences Journal 26 (7): 911-916, 2013.

Safiullin L.N., Gafurov I.R., Shaidullin R.N., Safiullin N.Z. Socio-economic development of the region and its historical and cultural heritage. Life Science Journal 2014; 11(6s): 400-404.

Storey, D., Johnson, S. Job Generation and Labour Market Change, Macmillan, London, 1987. p. 126.

Acs Z., Szerb L. Entrepreneurship, economic growth and public policy. Small Business Economics, Vol. 28, No. 2/3, March, 2007, pp. 109-122

Smallbone D., Welter F. Entrepreneurship and the role of government in post-socialist economies: some institutional changes. Historical Social Research / Historische Sozialforschung, Vol. 35, No. 2 (132), 2010, pp. 320-33.

Ajupov A.A., Polteva T.V. Handling depositary receipts for global financial markets. Life Science Journal 2014; 11(6s): 464 - 468.

Safiullin M.R., Samigullin I.G. and Safiullin L.N. Model of Management of Competitiveness of a Machine-building Complex/l World Applied Sciences Journal, 27(13), 2013, pp. 212-216.

Acs Z., Desai S., Hessels J. Entrepreneurship, economic development and institutions. Small Business Economics, Vol. 31, No. 3 , Special Issue: Entrepreneurship, Economic Development and Institutions, October 2008, pp. 219-234. 
